Prepared in cooperation with the Puerto Rico Department of Natural and Environmental Resources

\title{
Potentiometric Surface and Hydrologic Conditions of the South Coast Aquifer, Santa Isabel Area, Puerto Rico, March-April, 2014
}

Pamphlet to accompany

Scientific Investigations Map 3455 



\section{Potentiometric Surface and Hydrologic Conditions of the South Coast Aquifer, Santa Isabel Area, Puerto Rico, March-April, 2014}

By Félix A. Ramos and Alex A. Santiago

Prepared in cooperation with the Puerto Rico Department of Natural and Environmental Resources

Pamphlet to accompany

Scientific Investigations Map 3455 


\title{
U.S. Department of the Interior DAVID BERNHARDT, Secretary
}

\author{
U.S. Geological Survey \\ James F. Reilly II, Director
}

\section{U.S. Geological Survey, Reston, Virginia: 2020}

For more information on the USGS - the Federal source for science about the Earth, its natural and living resources, natural hazards, and the environment-visit https://www.usgs.gov or call 1-888-ASK-USGS.

For an overview of USGS information products, including maps, imagery, and publications, visit https://store.usgs.gov.

Any use of trade, firm, or product names is for descriptive purposes only and does not imply endorsement by the U.S. Government.

Although this information product, for the most part, is in the public domain, it also may contain copyrighted materials as noted in the text. Permission to reproduce copyrighted items must be secured from the copyright owner.

Suggested citation:

Ramos, F.A., and Santiago, A.A., 2020, Potentiometric surface and hydrologic conditions of the South Coast aquifer, Santa Isabel area, Puerto Rico, March-April, 2014: U.S. Geological Survey Scientific Investigations Map 3455, 4 p., 1 sheet, https://doi.org/10.3133/sim3455.

Associated data for this publication:

Ramos, F.A., and Santiago, A.A., 2019, Data and shapefiles for the potentiometric surface of the South Coast aquifer and hydrologic conditions in the Santa Isabel area, Puerto Rico, March-April 2014: U.S. Geological Survey data release, https://doi.org/10.5066/F7NSOSTO.

ISSN 2329-132X (online) 


\section{Acknowledgments}

The authors acknowledge the generous support of the farm owners in the Santa Isabel area who allowed access to their properties during the study period. The authors also thank U.S. Geological Survey (USGS) employees José M. Rodríguez, Sigfredo Torres-González and Coralis Conty for providing technical and editorial reviews of the manuscript and map; Marilyn Santiago, Xavier Marti, and Melissa Figueroa-Santos for the map development; Yaniré Martínez for the logistic support provided to conduct the streamflow measurements; and the entire crew of hydrologic technicians involved in data collection for this study. The authors also appreciate the editorial and technical reviews of USGS employees Kim H. Haag, Sandra Kinnaman, and Scott T. Prinos, whose substantive comments and suggestions greatly improved this document. 



\section{Contents}

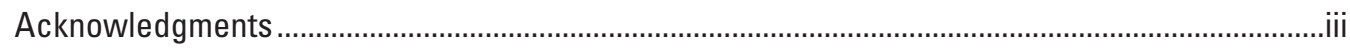

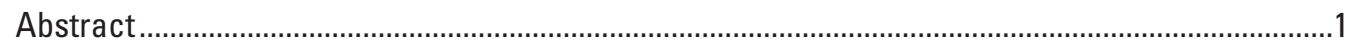

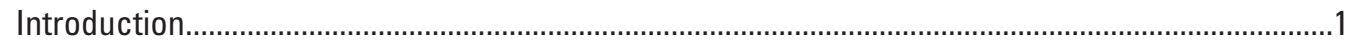

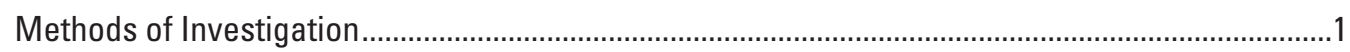

Hydrologic Conditions and the Estimated Potentiometric Surface ...................................................2

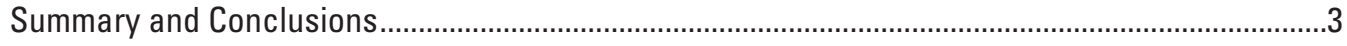

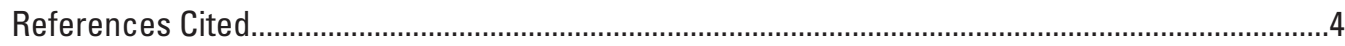

\section{Sheet}

Available for downloading from https://doi.org/10.3133/sim3455

1. Potentiometric surface and hydrologic conditions of the South Coast aquifer, Santa Isabel area, Puerto Rico, March-April, 2014

\section{Figure}

1. Graph showing groundwater levels and rainfall at Alomar Oeste observation well Santa Isabel, Puerto Rico, March 31 to April 17, 2014 .2

\section{Table}

1. Storage capacity of irrigation ponds in the Río Descalabrado to Río Jueyes area, Santa Isabel, Puerto Rico, March to April $2014 .$. 


\section{Conversion Factors}

Inch/Pound to International System of Units

\begin{tabular}{lcl}
\hline \multicolumn{1}{c}{ Multiply } & By & \multicolumn{1}{c}{ To obtain } \\
\hline inch (in.) & Length & \\
foot (ft) & 2.54 & centimeter $(\mathrm{cm})$ \\
& 0.3048 & meter $(\mathrm{m})$ \\
\hline square foot $\left(\mathrm{ft}^{2}\right)$ & Area & \\
\hline & 0.0929 & square meter $\left(\mathrm{m}^{2}\right)$ \\
\hline million gallons $(\mathrm{Mgal})$ & Volume & cubic meter $\left(\mathrm{m}^{3}\right)$ \\
\hline & 3,785 & \\
\hline cubic foot per second $\left(\mathrm{ft}^{3} / \mathrm{s}\right)$ & Flow rate & cubic meter per second $\left(\mathrm{m}^{3} / \mathrm{s}\right)$ \\
\hline
\end{tabular}

\section{Datum}

Vertical coordinate information is referenced to local mean sea level.

Horizontal coordinate information is referenced to the North American Datum of 1927 (NAD 27).

Altitude, as used in this report, refers to distance above the vertical datum. 


\title{
Potentiometric Surface and Hydrologic Conditions of the South Coast Aquifer, Santa Isabel Area, Puerto Rico, March-April, 2014
}

\author{
By Félix A. Ramos and Alex A. Santiago
}

\begin{abstract}
A potentiometric surface map of the South Coast aquifer near Santa Isabel, Puerto Rico, was created from data collected during a synoptic survey of groundwater levels at 55 wells from March 31 to April 17, 2014. Measured groundwater level values ranged from -22.8 to 185.4 feet above mean sea level. During the study period, cumulative rainfall of 0.65 inch was recorded in the study area. Measurements of instantaneous streamflow at 15 locations in streams and irrigation canals, and locations of irrigation ponds, provide additional information about the hydrologic setting. Results of the study indicate a cone of depression was present near the center and eastern parts of the Santa Isabel area of southern Puerto Rico, and a small, deeper cone of depression existed west of Santa Isabel and Rio Coamo. These cones of depression represent areas where the potentiometric surface was below mean sea level. The long-term persistence of such conditions could result in seawater intrusion and an increase in concentrations of total dissolved solids within the South Coast aquifer.
\end{abstract}

\section{Introduction}

Santa Isabel is a small town located in south-central Puerto Rico with a population of 23,274 (U.S. Census Bureau, 2010). The town is bordered by the municipalities of Coamo to the north, Juana Díaz to the west, Salinas to the east, and by the Caribbean Sea to the south. The South Coast aquifer underlies the town and consists of alluvial and associated clastic deposits within the Santa Isabel area that range in thickness from 0 feet (ft) along the foothills to 3,700 ft at the coast (Rodríguez-del-Río and Gómez-Gómez, 1990). Most water-supply wells penetrate less than $200 \mathrm{ft}$ below land surface. Below $250 \mathrm{ft}$, the unconsolidated deposits become finer-grained and yields to deep wells are not increased relative to shallower wells (Rodríguez-del-Río and Gómez-Gómez, 1990).

The U.S. Geological Survey (USGS) conducted a synoptic survey of the South Coast aquifer in the
Santa Isabel area, in cooperation with the Puerto Rico Department of Natural and Environmental Resources, during March-April 2014. The objectives of the study were to (1) document hydrologic conditions during the extended drought of 2012-15 in the South Coast aquifer, and (2) delineate the potentiometric surface of the South Coast aquifer between the Río Descalabrado and the Río Jueyes.

Documenting extreme hydrologic conditions helps to characterize groundwater flow during a period of rainfall deficiencies, which has been as much as 35 percent below average in recent years (Torres-González and Rodríguez, 2015). The climate of the southern coastal plain of Puerto Rico is influenced by the general topography of the island, which interacts with the eastern and southern winds creating a rain-shadow effect. Along the southern coastal plain, this effect greatly reduces mean annual rainfall from north to south, changing the general landscape from forest-humid to desert-dry (Rodríguez, 2013). A potentiometric surface map of the South Coast aquifer was created as part of the investigation to identify the direction of groundwater flow in the aquifer.

\section{Methods of Investigation}

A synoptic survey of groundwater levels in 55 wells and a field reconnaissance of the hydrologic conditions in the Santa Isabel area of the South Coast aquifer were conducted from March 31 to April 17, 2014. Measurements of instantaneous streamflow were made at 15 selected sites along the Río Coamo, Río Descalabrado, Río Cañas, and the Canal de Juana Díaz to constrain the potentiometric surface. Data used to generate the potentiometric surface and the potentiometric contours are available online (U.S. Geological Survey, 2018; Ramos and Santiago, 2019)

The potentiometric surface was delineated by measuring water-level altitudes in USGS observation wells in the study area and in pumping wells that were either not operating during the survey period or shut down briefly so that water-level measurements could be made. In the latter case, measurements were made after a recovery period of 30 minutes so that drawdown in the wellbore achieved a near-static-level 
representation of the aquifer at the measurement point (Rodríguez and others, 2005). The water-surface altitude was referenced to the mean sea level datum from USGS 1:20,000-scale maps for Santa Isabel, Rio Descalabrado, Coamo, and Salinas quadrangles (Doyle and Smith, 2012).

The aquifer in the study area is heterogenous, being composed of unconfined, semiconfined, and confined zones; however, well-depth and construction data are insufficient to adequately distinguish the vertical zones penetrated by the majority of wells. Thus, the potentiometric surface map is presented as a planar, two-dimensional feature, assuming hydrologic connectivity between zones of variable confinement (Prinos, 2005). The potentiometric-surface contours were delineated using water-level data, and more qualitatively informed by surface hydrologic features such as irrigation ponds, canals, drainage ditches, and saturated intermittent streams, as well as topographic settings (Rodríguez, 2013).

\section{Hydrologic Conditions and the Estimated Potentiometric Surface}

The potentiometric surface map (sheet 1) and hydrologic conditions presented herein represent dry-season conditions in the study area, which typically occur during the months of December through April (Kuniansky and others, 2004), as well as conditions during a multiyear drought. Drought conditions during 2014 were indicated by substantial rainfall deficits, relative to the 30 -year moving average, starting in 2012, at multiple, long-term rainfall National Oceanic and Atmospheric Administration monitoring stations in the area overlying the South Coast aquifer (Torres-Gonzalez and Rodriguez, 2016). During March and April 2014, groundwater levels and streamflow were seasonally low, and agricultural irrigation withdrawals were assumed to be high to meet crop demands during these extremely dry conditions. The mean annual rainfall at the Santa Isabel rain gage 50106100 is 36.27 inches (in.) (National Weather Service, 2010). Two separate rainfall events (April 3 and April 9, 2014) occurred during the study period, and a total rainfall of 0.65 in. was recorded for those dates at Alomar Oeste observation well (USGS station number 175734066233300, fig. 1). Rainfall on April 3, 2014, corresponds with a 0.54-ft increase in groundwater levels at the Alomar Oeste observation well; rainfall accumulation on April 9, 2014, also corresponds with an increase in groundwater levels at this well (fig. 1).

Measured groundwater level values collected during the study period ranged from -22.8 to 185.4 feet above mean sea level. Groundwater-level data indicate that a large cone of depression was present near the center and eastern parts of the Santa Isabel area of southern Puerto Rico, and a smaller, deeper cone of depression existed west of Santa Isabel and

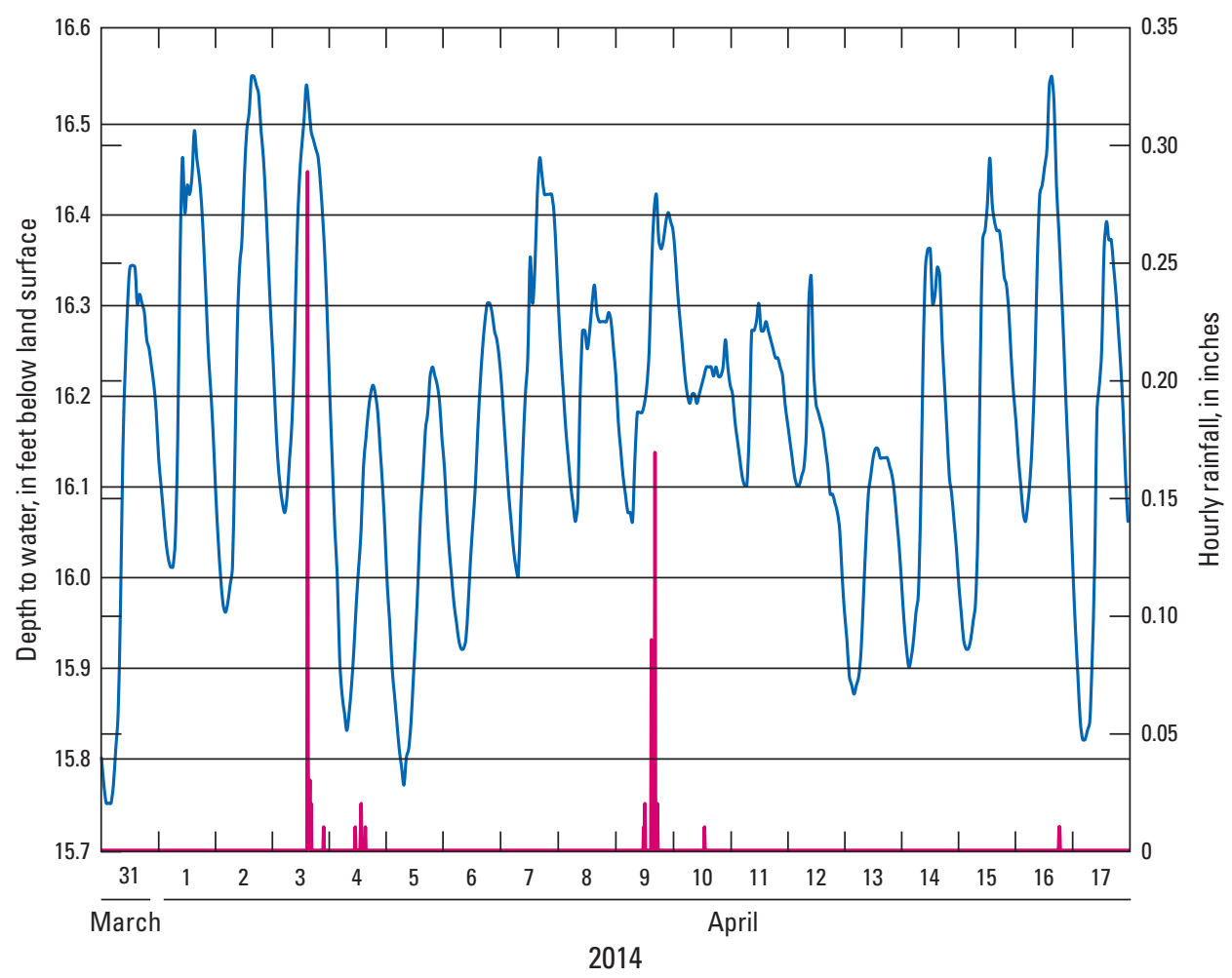

Figure 1. Groundwater levels and rainfall at Alomar Oeste observation well (station 175734066233300), Santa Isabel, Puerto Rico, March 31 to April 17, 2014. 
Rio Coamo (sheet 1). These cones of depression represent areas where the potentiometric surface was below mean sea level. Long-term persistence of groundwater levels in the South Coast aquifer below sea level could lead to saline-water intrusion and an increase in concentrations of total dissolved solids in groundwater.

The potentiometric surface that represents conditions in the aquifer during March-April 2014 can be compared to that determined from data collected in March 1987

(Rodríguez-del-Río and Gómez-Gómez, 1990). The comparison of these potentiometric surfaces indicates that groundwater levels in the aquifer were about $39 \mathrm{ft}$ lower on average during March-April 2014 than during March 1987. During and prior to 1987 , sugarcane was the main crop harvested in the area, and farmers used furrow irrigation techniques (Rodríguez-del-Río and Gómez-Gómez, 1990). During the early 1990s, furrow irrigation was replaced by drip irrigation, which is a more efficient irrigation method. The change to drip irrigation reduced the aquifer recharge, because most of the irrigation water applied is used by the crops or returned to the atmosphere by evapotranspiration. As a result, no appreciable amounts of water are returned to the aquifer as recharge under current irrigation methods (Kuniansky and others, 2004).

Instantaneous streamflow was measured at selected sites along the Río Coamo, Río Descalabrado, Río Cañas, and the Canal de Juana Díaz and used to qualitatively constrain the potentiometric surface during the timeframe of the synoptic survey. Where streamflow was present, the potentiometric surface was assumed to intersect the streambed; where streamflow was zero, the stream was dry, and the potentiometric surface was assumed to not intersect the streambed. During the study, the Río Coamo, Río Descalabrado, and Río Jueyes were flowing along their upstream reaches, north of Puerto Rico Highway 52; flow in the downstream reaches along the south coastal plain diminished southward until it was intermittent or absent. Streamflow measured in the Canal de Juana Díaz between the Río Cañas and Río Jueyes on March 19, 2014, ranged from 20.4 to 7.3 cubic feet per second. Streamflow in the Canal de Juana Díaz decreased substantially in the reach between the Río Coamo and Río Jueyes area, most likely because of the diversion of surface water to irrigation ponds in this area.

Water diversion from the Canal de Juana Díaz replenishes 11 irrigation ponds within the study area that were in operation during the survey. These 11 irrigation ponds are used to complement and reduce continued groundwater withdrawals in the area. Irrigation ponds represent areas where recharge to the aquifer, and associated potentiometric mounding, may be occurring. This information was used to qualitatively guide placement of the potentiometric contours. The surface area of the irrigation ponds was calculated using the original engineering drawings provided by the U.S. Department of Agriculture and verified with satellite-georeferenced photographs. The corresponding areas and volumes of the irrigation ponds are summarized in table 1 .
Table 1. Storage capacity of irrigation ponds in the Río Descalabrado to Río Jueyes area, Santa Isabel, Puerto Rico, March to April 2014.

[NAD 27, North American Datum of 1927; $\mathrm{ft}^{2}$, square foot; Mgal, million gallons]

\begin{tabular}{lcrc}
\hline \multicolumn{1}{c}{$\begin{array}{c}\text { Pond } \\
\text { name }\end{array}$} & $\begin{array}{c}\text { Latitude / longitude } \\
\text { (NAD 27) }\end{array}$ & $\begin{array}{c}\text { Area } \\
\left.\text { (ft }^{2}\right)\end{array}$ & $\begin{array}{r}\text { Volume } \\
\text { (Mgal) }\end{array}$ \\
\hline Doble A Pond & $175835.80 / 662343.96$ & $142,148.1$ & 7.21 \\
Doble B Pond & $175837.64 / 662343.26$ & $37,027.8$ & 2.73 \\
Celso Pond & $175911.44 / 662319.67$ & $94,765.4$ & 5.12 \\
La Guancha Pond & $175955.58 / 662247.05$ & $116,336.2$ & 6.26 \\
Portalatín Pond & $175836.43 / 662249.21$ & $105,755.3$ & 6.31 \\
La Muerta Pond & $175900.63 / 662230.32$ & $113,376.2$ & 6.57 \\
Cardona Pond & $175936.77 / 662221.37$ & $115,485.9$ & 6.65 \\
Sergio Pond & $175839.86 / 662206.10$ & $76,143.8$ & 4.02 \\
Grande Pond & $175940.35 / 662156.14$ & $201,349.5$ & 14.83 \\
Paso Seco Pond 1 & $180055.17 / 662441.80$ & $140,285.9$ & 10.33 \\
Paso Seco Pond 2 & $180102.28 / 662456.53$ & $107,326.8$ & 7.90 \\
\hline Total & & $\mathbf{1 , 2 5 0 , 0 0 1}$ & $\mathbf{7 7 . 9 3}$ \\
\hline
\end{tabular}

\section{Summary and Conclusions}

Groundwater-level data collected during the study period from March to April 2014 indicate that a large cone of depression, where the potentiometric surface was below mean sea level, existed near the center and eastern parts of the Santa Isabel area of southern Puerto Rico, and a small, deeper cone of depression existed west of Santa Isabel and Rio Coamo. The presence of groundwater levels in the South Coast aquifer below sea level for extended periods of time could lead to seawater intrusion and an increase in concentrations of total dissolved solids in groundwater.

Instantaneous streamflow measurements were made at selected sites along the Río Coamo, Río Descalabrado, Río Cañas, and the Canal de Juana Díaz. The Río Coamo, Río Descalabrado, and Río Jueyes were flowing along their upstream reaches north of Puerto Rico Highway 52, but flow in the downstream reaches on the south coastal plain diminished southward until it was intermittent or absent. Streamflow measured in the Canal de Juana Díaz between the Río Cañas and Río Jueyes ranged from 20.4 to 7.3 cubic feet per second. A substantial decrease in streamflow along the Canal de Juana Díaz occurred in the reach between the Río Coamo and Río Jueyes, most likely caused by the diversion of surface water to irrigation ponds in this area. These irrigation ponds are used as an alternative to continued groundwater withdrawals in the area and may provide recharge to the aquifer. 


\section{References Cited}

Doyle, D.R., and Smith, D.A., 2012, Definition and densification of the Puerto Rico vertical datum of 2002: Surveying and land information science, v. 72, no. 3, p. 109-118.

Kuniansky, E.L., Gomez-Gomez, F., and Torres-Gonzalez, S., 2004, Effects of aquifer development and changes in irrigation practices on ground-water availability in the Santa Isabel area, Puerto Rico: U.S. Geological Survey Water-Resources Investigations Report 03-4303, 56 p.

National Weather Service, 2010, Santa Isabel normals 1981 to 2010: National Weather Service database accessed October 2014 at http://www.srh.noaa.gov/sju/?n=climo_ santa isabel.

Prinos, S.T., 2005, Correlation analysis of a ground-water level monitoring network, Miami-Dade County, Florida: U.S. Geological Survey Open-File Report 2004-1412, accessed December 2015 at http://pubs.usgs.gov/ of/2004/1412/index.html.

Ramos, F.A., and Santiago, A.A., 2019, Data and Shapefiles for the potentiometric surface of the South Coast aquifer and hydrologic conditions in the Santa Isabel area, Puerto Rico, March-April 2014: U.S. Geological Survey data release, https://doi.org/10.5066/F7NS0STQ.

Rodríguez, J.M., 2013, Evaluation of groundwater quality and selected hydrologic conditions in the South Coast aquifer, Santa Isabel area, Puerto Rico, 2008-09: U.S. Geological Survey Scientific Investigations Report 2012-5254, 36 p.
Rodríguez, J.M., Santiago-Rivera, L., and Gómez-Gómez, F., 2005, Potentiometric surface of the alluvial aquifer and hydrologic conditions in the Juana Díaz area, Puerto Rico, June 29-July 1, 2005: U.S. Geological Survey Scientific Investigations Map 2947, 1 sheet.

Rodríguez-del-Río, F., and Gómez-Gómez, F., 1990, Potentiometric surface of the alluvial aquifer and hydrologic conditions in the Santa Isabel-Juana Díaz area, Puerto Rico, March to April 1987: U.S. Geological Survey Water-Resources Investigations Report 89-4116, 1 sheet.

Torres-González, S., and Rodríguez, J.M., 2016, Hydrologic conditions in the South Coast aquifer, Puerto Rico: U.S. Geological Survey Open-File Report 2015-1215, 32 p., accessed January 2016 at https://doi.org/10.3133/ ofr20151215.

U.S. Census Bureau, 2010, Annual estimates of the resident population for selected age groups by sex for the United States, States, counties, and Puerto Rico Commonwealth and municipios-April 1, 2010, to July 1, 2013: Accessed December 2015 at https://factfinder.census.gov/faces/nav/ jsf/pages/index.xhtml.

U.S. Geological Survey, 2018, USGS water data for the Nation: U.S. Geological Survey National Water Information System database, accessed May 8, 2018, at https://doi. org/10.5066/F7P55KJN. 
For more information about this publication, contact

Director, Caribbean-Florida Water Science Center

U.S. Geological Survey

4446 Pet Lane, Suite 108

Lutz, FL 33559

(813) 498-5000

For additional information visit

https://www2.usgs.gov/water/caribbeanflorida/index.html

Publishing support provided by

Lafayette Publishing Service Center 
